\title{
POZIOM WYKSZTAŁCENIA ZASOBÓW WIEJSKIEJ SIŁY ROBOCZEJ W POLSCE. ANALIZA PRZESTRZENNA
}

\section{EDUCATION LEVEL OF RURAL WORKFORCE IN POLAND. SPATIAL ANALYSIS}

\author{
Wioletta KAMIŃSKA \\ Uniwersytet Jana Kochanowskiego w Kielcach \\ Instytut Geografii \\ ul. Świętokrzyska 15, 25-406 Kielce \\ wioletta.kaminska@ujk.edu.pl
}

\begin{abstract}
Zarys treści: Celem pracy było określenie stopnia zróżnicowania poziomu wykształcenia zasobów wiejskiej siły roboczej w Polsce, porównanie poziomu wykształcenia tych zasobów w układzie wieś-miasto oraz sformułowanie prawidłowości w rozmieszczeniu wiejskiej siły roboczej o określonym poziomie wykształcenia. W badaniu przyjęto, że zasoby siły roboczej stanowią osoby w wieku produkcyjnym. Na podstawie badań można stwierdzić, że poziom wykształcenia siły roboczej w 2011 r. na wsi był niższy aniżeli w miastach i Polsce ogółem, ale w stosunku do 2002 r. uległ zdecydowanej poprawie. Kwalifikacje formalne mieszkańców wsi w wieku mobilnym były wyższe aniżeli w wieku niemobilnym. Rozmieszczenie wiejskiej siły roboczej z wykształceniem wyższym i średnim nawiązywało do lokalizacji aglomeracji. Bliskość miast i funkcje pozarolnicze były czynnikami sprzyjającymi kumulacji najlepiej wykształconej kadry, podobnie jak tereny odległe od szlaków komunikacyjnych i zróżnicowanych miejskich rynków pracy były obszarami odpływu kapitału ludzkiego o wysokiej jakości. Badania potwierdziły także, że rolnictwo, zwłaszcza na obszarach z dominacją (w przeszłości) państwowych gospodarstw rolnych, utrwaliło niekorzystną strukturę wykształcenia zasobów siły roboczej.
\end{abstract}

Słowa kluczowe: zasoby siły roboczej, wykształcenie, obszary wiejskie.

\section{Wstęp}

Od końca lat 90. XX w. badania dotyczące wzrostu gospodarczego były skoncentrowane głównie na znaczeniu jakości kapitału ludzkiego w pozytywnych przemianach ekonomicznych w poszczególnych krajach i regionach świata (Neycheva 2013). Podnoszono przy tym problem wykształcenia zasobów siły roboczej oraz jego dostosowania do potrzeb zmieniającego się rynku pracy. Z badań wynikało (por. np. Petrolongo i Pissarides 2001), że dysharmonia jakościowa na rynku pracy miała negatywny wpływ na jego efektywność, czego konsekwencją był wzrost bezrobocia oraz związane z tym wykluczenie społeczne i obniżanie się poziomu życia ludności. 
Nierównowaga w zakresie umiejętności pracowników dotknęła głównie państwa słabiej rozwinięte, w tym postsocjalistyczne. Niska zazwyczaj jakość kształcenia i brak związku między profilem szkolnictwa a specjalizacją regionalną potęgowały problemy na rynku pracy, zwłaszcza w okresie transformacji ustrojowej (Sondergaard i Murthi 2012).

Na przełomie XX i XXI w. ciągła restrukturyzacja gospodarek transformujących się, innowacje i globalizacja doprowadziły do dalszego wzrostu niedopasowania kwalifikacji siły roboczej do potrzeb rynku pracy (Labour Markets and Employability.... 2011; Arandarenko i Bartlett 2012; Barlett 2013). Szczególnie trudna sytuacja pod tym względem wystąpiła na obszarach wiejskich. Tereny te posiadały zwykle monofunkcyjny (rolniczy) charakter, który nie sprzyjał tworzeniu przewagi konkurencyjnej. Receptą na to był rozwój pozarolniczych działów gospodarczych, które stworzyły popyt na wysoko wykształconą siłę roboczą. Dotychczasowe kwalifikacje mieszkańców wsi okazały się niewystarczające.

Dynamiczne zmiany technologiczne i innowacyjne utrudniają obecnie racjonalne przewidywanie, jakie umiejętności i kwalifikacje będą poszukiwane na rynkach pracy w przyszłości (Bartlett 2013). Przyjmuje się jednak, że ludność z wysokim poziomem wykształcenia szybko dostosowuje się do zmieniającego się otoczenia, efektywnie reaguje na nowe możliwości rozwoju oraz kreatywnie rozwiązuje pojawiające się problemy społeczne, gospodarcze i kulturowe.

Powstaje pytanie, jaki jest obecnie (w 2011 r.) poziom kwalifikacji formalnych wiejskich zasobów siły roboczej w Polsce. Jest to ważny problem badawczy, który należy rozpatrywać w szerokim kontekście negatywnych prognoz demograficznych. Zakładają one, że liczba ludności w kraju będzie się zmniejszać. Spadkowi ulegnie także liczba ludności w wieku produkcyjnym, a obniżanie się dzietności i wydłużanie się ludzkiego życia doprowadzi nieodwracalnie do starzenia się społeczeństwa, zaś w konsekwencji do nadwyżki popytu nad podażą na rynku pracy. Polskie obszary wiejskie mogą więc stanowić rezerwuar siły roboczej, co przecież w przeszłości wielokrotnie miało już miejsce (Turowski 1978; Witkowski 2005; Zegar 2012).

Celem pracy jest określenie stopnia zróżnicowania poziomu wykształcenia zasobów wiejskiej siły roboczej w Polsce, porównanie poziomu wykształcenia tych zasobów w układzie wieś-miasto oraz określenie prawidłowości w rozmieszczeniu wiejskiej siły roboczej o określonym poziomie wykształcenia. Nadto przedstawiono zróżnicowanie przestrzenne poziomu wykształcenia mobilnej siły roboczej, czyli ludności w wieku do 44 lat.

W badaniu przyjęto, że zasoby siły roboczej stanowią osoby w wieku produkcyjnym. W pracy wykorzystano dane dotyczące liczby osób na poszczególnych poziomach wykształcenia na obszarach wiejskich. Dane te zostały udostępnione przez Główny Urząd Statystyczny na specjalne zamówienie i pochodziły ze Spisu Powszechnego 2011 r. Badanie przeprowadzono w przekroju powiatów. Wykorzystano podstawowe miary statystyczne oraz metody kartograficzne. Dla określenia prawidłowości przestrzennych w rozmieszczeniu zasobów siły roboczej wg wykształcenia zastosowano miernik obrazujący liczbę osób na danym poziomie edukacji na 1000 mieszkańców wsi w wieku produkcyjnym. Przyjmując jako kryterium ten wskaźnik, powiaty podzielono na grupy odznaczające się następującym poziomem natężenia liczby osób o danym poziomie wykształcenia badanej grupy ludności:

1. bardzo wysokim, jeżeli $d_{i} \geq \bar{d}_{i}+2 S_{0}$ (gdzie $\bar{d}_{i}$ średnia wskaźnika $d_{i} S_{0}$ odchylenie standardowe wskaźnika $d_{i}$ )

2. wysokim, jeżeli $\bar{d}_{i}+1 S_{0} \leq d_{i}<\bar{d}_{i}+2 S_{0}$ 
3. średnim, jeżeli $\left.\bar{d}_{i} \leq d_{i}<\bar{d}_{i}+1 S_{0}\right)$,
4. niskim, jeżeli $\bar{d}_{i}-1 S_{0} \leq d_{i}<\bar{d}_{i}$
5. bardzo niskim, jeżeli $d_{i} \leq \bar{d}_{i}-1 S_{0}$

\section{Ewolucja badań nad wykształceniem zasobów siły roboczej}

Na przełomie XX i XXI w. w wielu państwach świata nastąpiło przejście od gospodarki industrialnej (postindustrialnej) do opartej na wiedzy. Tak jak transformacja gospodarki z agrarnej do przemysłowej, tak i to przejście wywołało zmiany na rynku pracy wyrażające się m.in. nowymi wymaganiami w stosunku do kwalifikacji i umiejętności pracowników (Karoly 2010). W XXI w. edukacja zaczęła odgrywać coraz ważniejszą rolę w przygotowaniu nowych zasobów siły roboczej. Jak podkreślili Karoly i Panis (2004), kluczowa rola edukacji jest napędzana przez szybkie tempo zmian technologicznych.

Studia traktujące kwalifikacje pracowników jako główny element wzrostu gospodarczego pojawiły się w latach 60. XX w. ${ }^{1}$ i koncentrowały się głównie na indywidualnych i zbiorowych korzyściach obywateli wynikających z inwestowania w naukę i poszerzania swoich kwalifikacji. Dały one także podstawę do budowania endogenicznych modeli wzrostu, zakładających związek między poziomem wykształcenia ludności a wzrostem gospodarczym poszczególnych jednostek przestrzennych. W pierwszych modelach zakładano, że inwestycje na edukację siły roboczej należy traktować jako nakłady o wysokiej stopie zwrotu ze względu na jej wpływ na wiedzę i umiejętności zdobywane w procesie kształcenia się (Freeman 1986). Zakładano zależności między wykształceniem i postępem technicznym (Nelson i Phelps 1966; Lucas 1988) oraz między wiedzą a produktywnością i tempem dyfuzji technologii (Arrow 1962; Nelson i Phelps 1966; Romer 1990).

Modele wzrostu endogenicznego weryfikowano w badaniach empirycznych. Wyliczono stopę zwrotu inwestycji w edukację i podnoszenie kwalifikacji (Miller 1960; Becker 1964; Psacharopoulos i Patrinos 2004; Denny i O’Sullivan 2007; Jimenez i in. 2012), określono rolę wykształcenia we wzroście gospodarczym regionów (Kendrick 1961; Denison 1971; Heston i in. 2002; De la Fuente i Ciccone 2003; Kirchhoff i in. 2007; Jimenez i in. 2012) oraz oszacowano korzyści zewnętrzne z inwestycji w edukację (Acemoglu 1996; de Baross i in. 2000; McMahon 2001; Wilson i Briscoe 2004).

Wnioski z tych badań były zazwyczaj optymistyczne, bowiem wykazano, że stopa zysku z inwestycji w studia była prawie taka sama jak w przypadku nakładów inwestycyjnych na rynku kapitałowym, nieruchomości czy w lokaty bankowe (Miller 1960; Becker 1964), że wykształcenie zwiększało dochody indywidualne ponad wysokość nakładów (Psacharopoulos i Patrinos 2004), zmniejszało dyspersję płac (Jimenez i in. 2012) oraz mogło stanowić substytut innych czynników w generowaniu zysku (Denny i O’Sullivan 2007). Natomiast w sytuacji, gdy wyliczenia nie potwierdzały takiej zależności (por. Barro i Lee 1996; Caselli i in. 1996), autorom zarzucano stosowanie niewłaściwych metod lub wykorzystanie błędnych danych.

W XXI w. badania koncentrowały się bardziej na jakościowych niż ilościowych cechach wykształcenia. Stwierdzono, że rzeczywiste umiejętności są bardziej skorelowane z wielkością indywidualnych dochodów oraz wzrostem gospodarczym aniżeli liczbą lat pobie-

\footnotetext{
${ }_{1}$ Prace tego typu powstały już w XVII, XVIII i XIX w. Kwalifikacjami pracowników i ich wpływem na produktywność zajmowali się m.in. A. Smith, J.B. Say, K. Marks, J.S. Mill, S. Staszic.
} 
rania nauki w szkole (Hanushek i Woessmann 2008). Wykazano także, że dla wzrostu gospodarczego obok wiedzy na podstawowym poziomie ważne są umiejętności komunikacji, pracy w zespole oraz umiejętności charakterystyczne dla danego zawodu. Większość profesji wymagała bowiem mieszanki różnego rodzaju umiejętności na określonym poziomie (Jimenez i in. 2012).

W nowych warunkach, jakie stworzyły procesy globalizacji w połączeniu z technologiami informacyjnymi, na rynku pracy premiowane są umiejętności komunikowania się oraz zbierania i przetwarzania informacji, a także szybkiej adaptacji do zmieniającego się otoczenia. W gospodarce opartej na wiedzy docenia się umiejętności abstrakcyjnego myślenia, rozwiązywania problemów, komunikacji i współpracy (Karoly 2010). Jak wskazuje cytowana autorka, w związku z szybkim tempem zmian technologicznych w ostatnich dziesięcioleciach wzrósł popyt na najwyżej wykwalifikowanych pracowników, którzy mogą rozwijać nowe technologie, określić ich zastosowania w produkcji dóbr i usług, a także korzystać z technologii w miejscu pracy. W niektórych przypadkach nowe technologie zastępują pracę ludzką. Dlatego też pewne czynności stają się przestarzałe, podczas gdy inne zyskują na znaczeniu (Autor i in. 2003). W innych przypadkach na określone zawody nadal jest popyt, ale ich wykonywanie wymaga dodatkowych umiejętności, ponieważ pracownicy są zobowiązani do coraz szerszego wykorzystywania komputerów w swojej pracy (Karoly 2010). Badania D.H. Autora i in. (2003) potwierdziły, że komputeryzacja powoduje obniżenie zapotrzebowania na wykonywanie rutynowych zadań poznawczych oraz manualnych i wzrost popytu na kwalifikacje umożliwiające realizację czynności nieszablonowych oraz zadań służących rozwiązywaniu złożonych problemów wynikających z komunikowania się z ludźmi (ryc. 1).

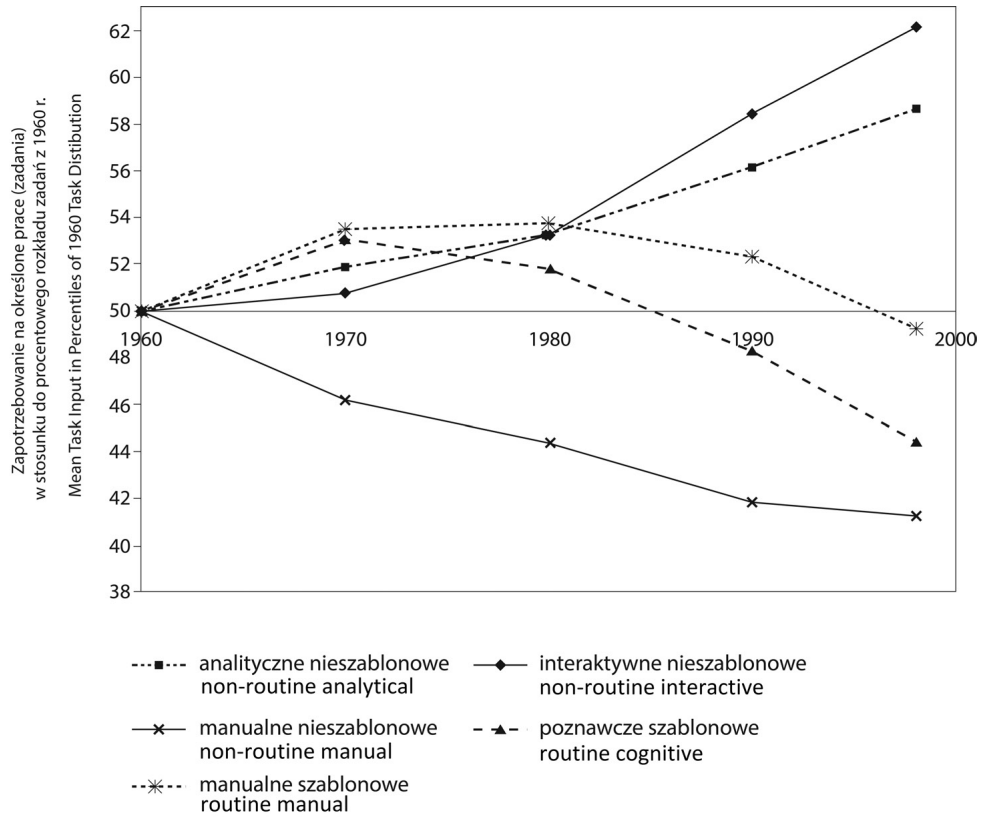

Ryc. 1. Trendy w rutynowych (szablonowych) i nierutynowych nakładach pracy w latach 1960-1998 Trends in Routine and Non-routine Task Input, 1960 to 1998

Źródło/Source: D. H. Autor i in. (2003). 
Wyniki badań jednoznacznie wskazywały na pozytywną zależność między zastosowaniem technologii komputerowych a zapotrzebowaniem na wykształconych pracowników (Berman i in. 1994; Berman i in. 1998; Bresnahan i in. 2002). Jednocześnie potwierdzono, że nowe technologie i innowacyjne rozwiązania będą pojawiać się coraz szybciej, a to z kolei będzie wywoływać dynamiczne zmiany na rynkach pracy. Uczenie się przez całe życie jest i będzie kluczem do sukcesu zawodowego (Karoly 2010; Labour Markets and Employability... 2011; Arandarenko i Bartlett 2012; Barlett 2013).

W Polsce także były prowadzone badania dotyczące jakości zasobów siły roboczej, ich wielkości i struktur demograficznych (por. np. Kamińska i Heffner 2012) oraz związków między wykształceniem ludności a różnymi aspektami wzrostu gospodarczego (por. np. Kulikowski 2002; Janc i Czapiewski 2005).

\section{Wykształcenie wiejskiej siły roboczej w Polsce w 2011 r.}

W latach 2002-2011 w Polsce zarówno w miastach, jak i na wsi nastąpił wyraźny wzrost odsetka osób z wykształceniem wyższym i średnim. Na koniec tego okresu ponad połowa obywateli kraju posiadała świadectwo ukończenia co najmniej szkoły średniej (tab. 1). I chociaż wskaźnik ten był o wiele niższy na obszarach wiejskich niż w miastach, to i tak co trzeci mieszkaniec wsi zakończył edukację przynajmniej na poziomie liceum (technikum). W porównaniu z rokiem wyjściowym ta grupa ludności wiejskiej powiększyła się o ponad 11 punktów procentowych

Tabela 1. Zmiany w strukturze wykształcenia mieszkańców miast i wsi w Polsce w latach 2002-2011

\begin{tabular}{|c|c|c|c|c|c|}
\hline \multirow{2}{*}{ Poziom wykształcenia } & \multirow{2}{*}{ Rok } & Polska & Miasta & Wieś & \multirow{2}{*}{$\begin{array}{l}\text { Różnica mię- } \\
\text { dzy miastem } \\
\text { a wsią (4-5) }\end{array}$} \\
\hline & & \multicolumn{3}{|c|}{ odsetek mieszkańców (\%) } & \\
\hline 1 & 2 & 3 & 4 & 5 & 6 \\
\hline \multirow{2}{*}{ Wyższe } & 2002 & 10,1 & 13,6 & 4,2 & 9,4 \\
\hline & 2011 & 17,9 & 22,7 & 10,3 & 12,4 \\
\hline \multirow{2}{*}{ Średnie i policealne } & 2002 & 32,1 & 38,4 & 21,7 & 16,7 \\
\hline & 2011 & 33,3 & 37,5 & 26,7 & 10,8 \\
\hline \multirow{2}{*}{ Zasadnicze zawodowe } & 2002 & 23,7 & 21,0 & 28,2 & $-7,2$ \\
\hline & 2011 & 22,9 & 19,8 & 27,6 & $-7,9$ \\
\hline \multirow{2}{*}{ Gimnazjalne i podstawowe } & 2002 & 30,4 & 24,6 & 40,0 & $-15,4$ \\
\hline & 2011 & 24,5 & 19,0 & 33,1 & $-14,1$ \\
\hline \multirow{2}{*}{ Bez wykształcenia szkolnego } & 2002 & 3,7 & 2,4 & 5,9 & $-3,5$ \\
\hline & 2011 & 1,4 & 0,9 & 2,2 & $-1,3$ \\
\hline Razem & $x$ & 100,0 & 100,0 & 100,0 & $x$ \\
\hline
\end{tabular}

Źródło: W. Kamińska (2014).

Zdecydowanie zmniejszyła się natomiast grupa osób z najniższym poziomem formalnych kwalifikacji (podstawowym i gimnazjalnym oraz bez wykształcenia szkolnego). Ogółem w kraju spadek ten wynosił ponad 8 punków procentowych, w miastach ok. 7 p.p., a na obszarach wiejskich prawie 11 p.p. Wynikało to z dwóch głównych powodów. 
Po pierwsze wystąpiło naturalne wymieranie ludności starszej, czyli grupy, wśród której udział osób z ukończoną tylko szkołą elementarną był najwyższy, po drugie nastąpił wzrost znaczenia wykształcenia w świadomości mieszkańców wsi, co spowodowało podnoszenie przez nich kwalifikacji w szkołach średnich (Baran 2011).

Tak korzystne trendy wywarły pozytywny wpływ na strukturę wykształcenia zasobów wiejskiej siły roboczej. Wśród tej grupy ponad 11\% osób miało ukończoną uczelnię wyższą, a prawie 1/3 posiadała dyplom ukończenia szkoły średniej lub policealnej (tab. 2). W dalszym ciągu były to niezbyt wysokie wskaźniki w porównaniu z krajem i z miastami, ale ponad 40\% udział ludności z wykształceniem średnim i wyższym należy uznać za korzystny. Na tak wysoki odsetek ludności o najwyższych kwalifikacjach formalnych w strukturze wykształcenia wiejskiej siły roboczej miało wpływ kilka czynników. Po pierwsze poprawa dostępności szkół wyższych i średnich związana z powstawaniem niepublicznych instytucji związanych ze szkolnictwem, rozwojem motoryzacji prywatnej, budową dróg dobrej jakości (por. Komornicki i Czapiewski 2010). Po drugie wzrost aspiracji zawodowych i życiowych młodzieży wiejskiej i ich rodziców (por. Baran 2011). Po trzecie trudności w znalezieniu pracy przez młodych ludzi o niskich kwalifikacjach (por. Ciok i Ilnicki 2012), co dawało asumpt do kontynuacji nauki dla podwyższania umiejętności, ale też do przeczekania kryzysu na rynku pracy.

Tabela 2. Struktura wykształcenia zasobów siły roboczej na obszarach wiejskich i miejskich w Polsce w 2011 r. (\%)

\begin{tabular}{|c|c|c|c|}
\hline Poziom wykształcenia & Wieś & Miasto & Polska \\
\hline Wyższe & 11,8 & 24,5 & 19,5 \\
\hline Średnie i policealne & 30,0 & 38,2 & 35 \\
\hline Zasadnicze zawodowe & 30,8 & 20,6 & 24,6 \\
\hline Gimnazjalne & 7,4 & 5,3 & 6,1 \\
\hline Podstawowe & 19,5 & 10,5 & 14,1 \\
\hline Bez wykształcenia szkolnego & 0,5 & 0,9 & 0,7 \\
\hline Razem & 100,0 & 100,0 & 100,0 \\
\hline
\end{tabular}

Źródło: Obliczenia własne na podstawie danych uzyskanych z GUS.

W strukturze wykształcenia siły roboczej duże znaczenie mieli absolwenci szkół zasadniczych zawodowych. Na wsi stanowili oni blisko 1/3 ogółu zasobów, a w miastach tylko 1/5. Jak wskazała E. Kacprzak (2010), w grupie młodzieży wiejskiej stwierdzono silne dążenie do zdobycia konkretnego zawodu. Związane to było w znacznej mierze z mentalnością ugruntowaną w minionych wiekach oraz intensywnym rozwojem szkolnictwa zawodowego w latach 70. i 80. XX w. Krótki okres kształcenia, dobra dostępność szkół zawodowych nie powodowały dużego obciążenia rodziny kosztami nauki, a młody człowiek szybko usamodzielniał się. Jednak, jak zauważyła cytowana autorka, to podejście powoli się zmieniało i młodzież coraz częściej wybierała kierunki ogólnokształcące.

W 2011 r. na wsi 20\% osób w wieku produkcyjnym posiadało najniższy poziom wykształcenia (podstawowe oraz bez wykształcenia szkolnego), podczas gdy w miastach grupa ta stanowiła ok. 12\%, a w kraju niecałe 15\%. Pomimo że i w tym zakresie zaobserwowano pozytywne zmiany (por. tab. 1), to jednak tak duża grupa o niskich kwalifikacjach nie jest dobrym prognostykiem na przyszłość, zwłaszcza w kontekście rozwoju gospodarki opartej na wiedzy. 
Należy jednak podkreślić, że młodsze pokolenie Polaków było lepiej wyedukowane niż starsze, o czym świadczyła struktura wykształcenia mobilnej siły roboczej (tab. 3). Podstawowe różnice między poziomem edukacji mobilnych zasobów pracowniczych a ogółem ludności w wieku produkcyjnym można ująć następująco:

1. Wśród mobilnej siły roboczej zanotowano wyższy odsetek osób z wykształceniem co najmniej średnim niż wśród wszystkich osób w wieku produkcyjnym. Różnica wynosiła w przypadku ludności po studiach 2,4 p.p., a przypadku absolwentów szkół średnich i policealnych prawie 2 p.p. Można przypuszczać, że młodsza grupa siły roboczej po pierwsze wykorzystała warunki, jakie stworzyła gospodarka rynkowa w zakresie dostępności szkół, po drugie bardziej rozumiała potrzebę permanentnego uczenia się, a po trzecie starała się dostosować do wyższych wymagań na rynkach pracy. Powyższa prawidłowość wystąpiła także w miastach i całym kraju.

Tabela 3. Struktura wykształcenia mobilnej siły roboczej na obszarach wiejskich i miejskich w Polsce w 2011 r. (\%)

\begin{tabular}{|c|c|c|c|}
\hline Poziom wykształcenia & Wieś & Miasta & Polska \\
\hline Wyższe & 14,2 & 29,0 & 23 \\
\hline Średnie i policealne & 31,9 & 36,1 & 34,4 \\
\hline Zasadnicze zawodowe & 25,3 & 14,6 & 18,9 \\
\hline Gimnazjalne & 11,4 & 8,9 & 9,9 \\
\hline Podstawowe & 16,1 & 10,6 & 12,9 \\
\hline Bez wykształcenia szkolnego & 1,1 & 0,8 & 0,9 \\
\hline Razem & 100,0 & 100,0 & 100,0 \\
\hline
\end{tabular}

Źródło: Obliczenia własne na podstawie danych GUS.

2. W zasobach wiejskiej siły roboczej do 44 roku życia odnotowano niższy o 5,5 p.p. odsetek osób z wykształceniem zasadniczym zawodowym niż w całej grupie ludności w wieku produkcyjnym. W miastach analogiczny wskaźnik był niższy o 6,1 p.p., a w kraju o 5,7 p.p. Było to związane głównie z polityką rządu w zakresie szkolnictwa. W latach 90. w Polsce, podobnie jak w wielu krajach europejskich, zdemontowano system szkolnictwa zawodowego. Zawodówki wówczas były opcją dla „przegranych”, dla tej grupy młodzieży, która nie radziła sobie z nauką. Jeszcze w roku szkolnym 1990/1991 szkoły zawodowe ukończyło blisko 250 tys. uczniów, a dwadzieścia lat później zaledwie 75 tys. (ryc. 2).

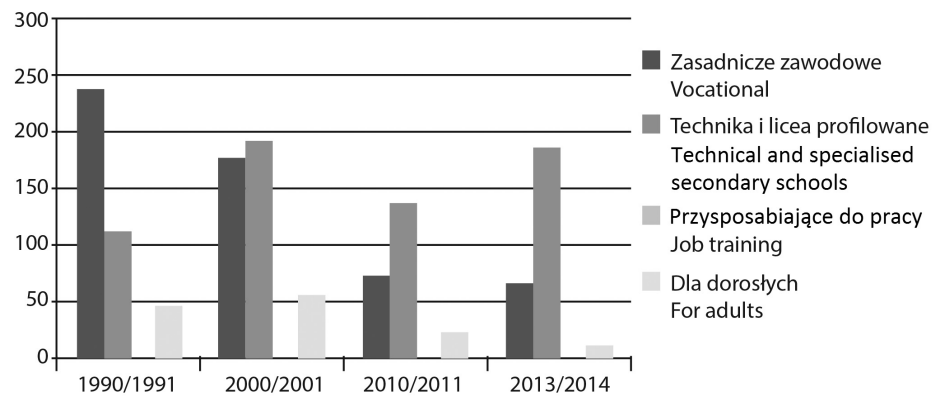

Ryc. 2. Szkolnictwo zawodowe w Polsce - liczba absolwentów (tys.)

Vocational education in Poland - number of graduates (thous.)

Źródło: GUS, opracowanie: Money.pl / Source: CSO, elaboration: Money.pl 
3. W grupie osób w wieku mobilnym na obszarach wiejskich zaobserwowano niższy o prawie 3 p.p. odsetek osób z najniższym poziomem kwalifikacji formalnych (podstawowym i bez wykształcenia szkolnego) aniżeli w całkowitych zasobach siły roboczej. Było to naturalne, zważywszy na zmieniające się funkcje obszarów wiejskich. Osoby reprezentujące obecnie starsze roczniki siły roboczej (wiek niemobilny) - to ludzie urodzeni w latach 1947-67, a więc ludność, która zdobywała swoje szkolne wykształcenie w czasach gospodarki centralnie sterowanej. Dominujące wówczas funkcje rolnicze na obszarach wiejskich nie kreowały popytu na wysoko kwalifikowaną kadrę. Proste prace w gospodarstwie rolnym nie wymagały wysokich kwalifikacji, więc gros mieszkańców wsi kończyło edukację na poziomie podstawowym. Nadto niskie wykształcenie rodziców, potrzeba ciągłej pomocy w gospodarstwie rolnym nie sprzyjały zdobywaniu wiedzy w szkole wiejskim dzieciom i młodzieży.

\section{Rozmieszczenie wiejskiej siły roboczej z wykształceniem wyższym w Polsce w 2011 r.}

W 2011 r. na obszarach wiejskich na 1000 osób w wieku produkcyjnym przypadało 108 z wykształceniem wyższym. Rozpiętość miedzy minimalną (53) i maksymalną (332) wartością tego wskaźnika wynosiła 279, co świadczyło o dużym jego zróżnicowaniu przestrzennym. Współczynnik zmienności kształtował się na poziomie 33,9\%.

Przyjmując jako kryterium wartość wskaźnika obrazującego liczbę osób z wykształceniem wyższym na 1000 mieszkańców wsi w wieku produkcyjnym, powiaty podzielono na 5 grup (tab. 4, ryc. 3).

Tabela 4. Zróżnicowanie przestrzenne wiejskiej siły roboczej z wykształceniem wyższym w Polsce w 2011 r.

\begin{tabular}{|c|c|c|}
\hline $\begin{array}{l}\text { Wskaźnik: } \\
\text { liczba osób z wykształceniem } \\
\text { wyższym na } 1000 \text { osób } \\
\text { w wieku produkcyjnym }\end{array}$ & $\begin{array}{l}\text { Liczba } \\
\text { powiatów }\end{array}$ & $\begin{array}{l}\text { Przykłady (pierwsze } 10 \text { z grupy) - w nawiasach wartość } \\
\text { wskaźnika }\end{array}$ \\
\hline $\begin{array}{l}\text { Bardzo wysoki } \\
\text { (184 i więcej) }\end{array}$ & 11 & $\begin{array}{l}\text { policki (332), pruszkowski (300), piaseczyński (298), legio- } \\
\text { nowski (272), poznański (265), warszawski zachodni (252), } \\
\text { wrocławski (232), będziński (204), grodziski (199), bydgoski } \\
\text { (188), mikołowski (187) }\end{array}$ \\
\hline $\begin{array}{l}\text { Wysoki } \\
(146-183)\end{array}$ & 20 & $\begin{array}{l}\text { krakowski (178), gdański (178), lubelski (173), bielski (172), } \\
\text { łódzki wschodni (170), otwocki (167), białostocki (165), zgier- } \\
\text { ski (162), pabianicki (160), bieruńsko-lędziński (159) }\end{array}$ \\
\hline $\begin{array}{l}\text { Średni } \\
(108-145)\end{array}$ & 89 & $\begin{array}{l}\text { chrzanowski (144), hajnowski (142), wielicki (140), socha- } \\
\text { czewski (140), rzeszowski (140), oświęcimski (137), skarżyski } \\
\text { (137), pszczyński (136), częstochowski (136), głogowski (136) }\end{array}$ \\
\hline $\begin{array}{l}\text { Niski } \\
(70-107)\end{array}$ & 183 & $\begin{array}{l}\text { szydłowiecki (107), opatowski (107), opoczyński (107), rycki } \\
\text { (107), jarosławski (107), makowski (1407), parczewski (107), } \\
\text { wieluński (106), wieruszowski (105), sieradzki (105) }\end{array}$ \\
\hline $\begin{array}{l}\text { Bardzo niski } \\
\text { (69 i mniej) }\end{array}$ & 11 & $\begin{array}{l}\text { dąbrowski (69), choszczeński (69), moniecki (69), sępoleński } \\
\text { (68), wałecki (67), szczecinecki (66), braniewski (64), drawski } \\
\text { (63), łobeski (62), iławski (58), białogardzki (53) }\end{array}$ \\
\hline Razem & 314 & $x$ \\
\hline
\end{tabular}

Źródło: Opracowanie własne na podstawie danych GUS. 


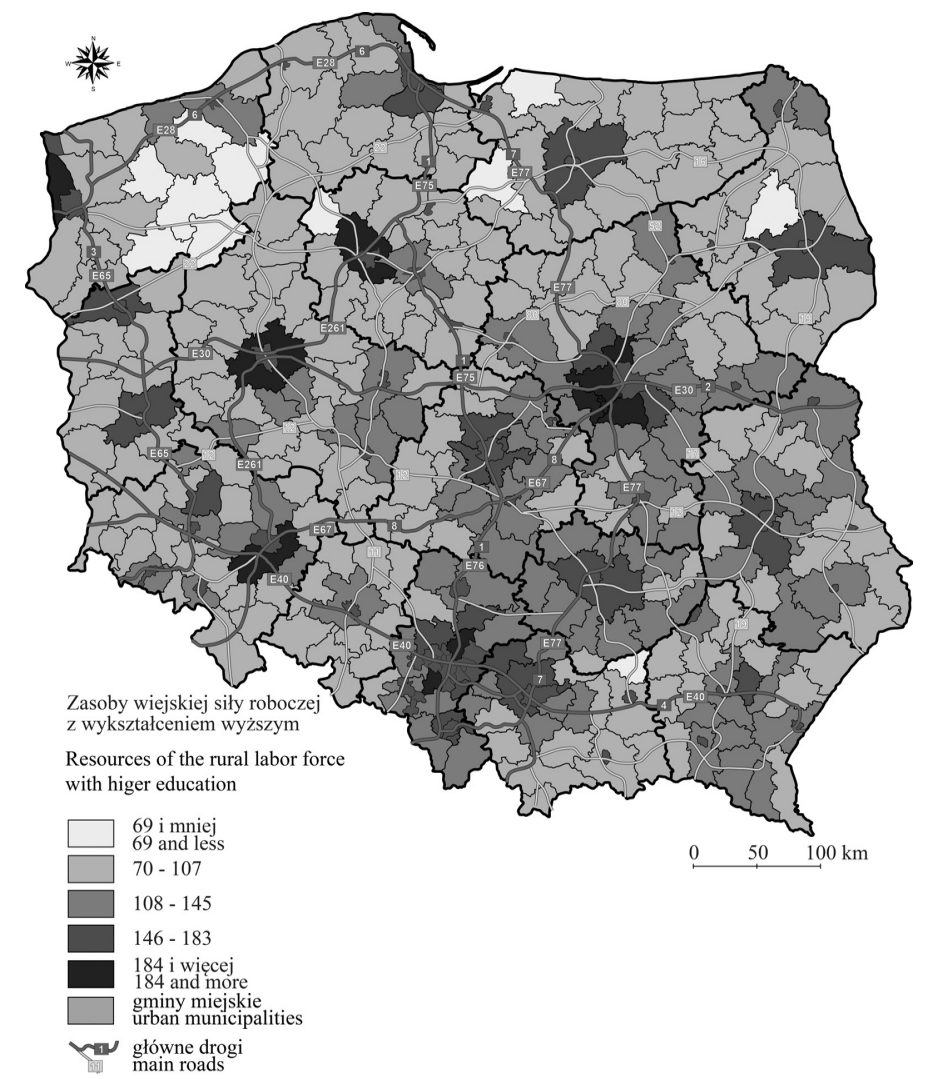

Ryc. 3. Liczba osób z wykształceniem wyższym na 1000 osób w wieku produkcyjnym na obszarach wiejskich w Polsce w $2011 \mathrm{r}$.

Number of people with higher education per 1,000 people at working age in rural areas in Poland in 2011

Źródło/Source: opracowanie własne/own elaboration.

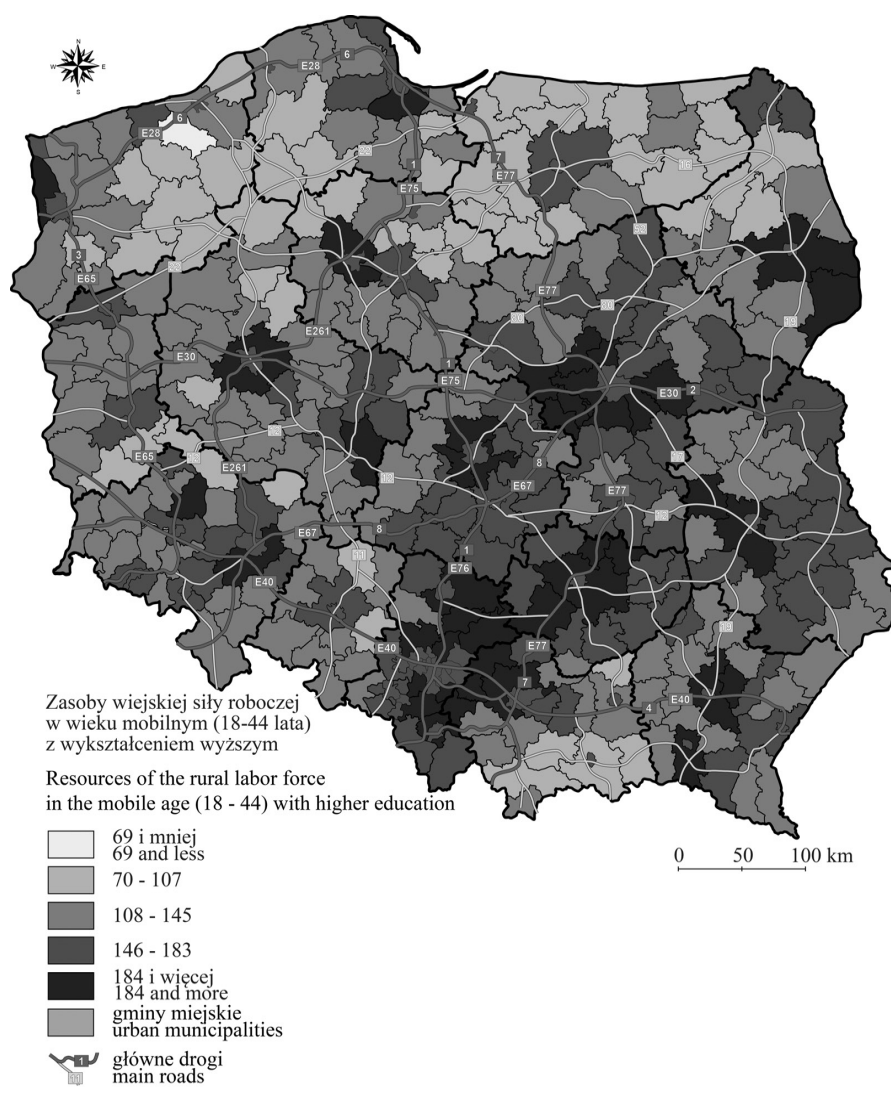

Ryc. 4. Liczba osób z wykształceniem wyższym w wieku mobilnym na 1000 osób w mobilnym wieku produkcyjnym na obszarach wiejskich w Polsce w 2011 r. Number of people with higher education in mobile age per 1,000 people at mobile working age in rural areas in Poland in 2011 Zródło/Source: opracowanie własne/own elaboration. 
Pierwsza i druga grupa obejmowały powiaty o bardzo wysokim wskaźniku (powyżej 184) i wysokim (146-183). Takich jednostek przestrzennych zidentyfikowano tylko 31 (9,9\% ich ogólnej liczby). Były to powiaty bezpośrednio sąsiadujące z aglomeracjami miejsko-przemysłowymi (wrocławski, warszawski zachodni, poznański) oraz o silnie wykształconych funkcjach przemysłowych jeszcze w okresie gospodarki centralnie sterowanej (policki, mikołowski, będziński, grodziski).

Trzecia grupa skupiała jednostki przestrzenne o średnich wartościach analizowanego wskaźnika (108-145). Była ona reprezentowana przez 89 powiatów (28,3\%), o funkcjach przemysłowych, które w poprzednim okresie ustrojowym kraju były ważnymi ośrodkami gospodarczymi Polski.

Czwarta i piata grupa skupiały obszary o niskich (70-107) i bardzo niskich (69 i mniej) wskaźnikach obrazujących liczę osób z wykształceniem wyższym na 1000 mieszkańców w wieku produkcyjnym. Łącznie takich powiatów było 194, co stanowiło ponad 60\% ich ogólnej liczby. Były to obszary rolnicze, położone peryferyjnie w stosunku do wiodących centrów gospodarczych Polski, dawnych okręgów przemysłowych (por. Fierla 1979) oraz granic wojewódzkich i krajowych.

Rozkład przestrzenny badanego wskaźnika można analizować w świetle teorii rdzeń-peryferia, przy czym za rdzenie należy uznać nie tylko największe polskie miasta, ale także dawne okręgi przemysłowe (warszawski, staropolski, tódzki, dolnośląski i górnośląsko-krakowska aglomeracja przemysłowa). Do tych obszarów nawiązywały powiaty cechujące się najwyższą (ponadprzeciętną) koncentracją siły roboczej z wykształceniem wyższym. Tereny peryferyjne, w tym rolnicze, odznaczały się niskim i bardzo niskim udziałem osób po studiach w strukturze zasobów siły roboczej. A zatem obecne rozmieszczenie osób o najwyższych kwalifikacjach formalnych było efektem nakładania się wielu czynników oddziałujących ze zmiennym natężeniem w czasie i przestrzeni: renty położenia (bliskość wielkich miast, dostępność uczelni), rozwoju funkcji pozarolniczych, głównie przemysłowych w okresie centralnego sterowania i współczesnych migracji na linii miasto-wieś osób dobrze wykształconych.

Inaczej przedstawiało się rozmieszczenie ludności z wykształceniem wyższym w wieku mobilnym. W 2011 r. przeciętnie na 1000 osób w wieku do 44 lat przypadało 114 z ukończonymi studiami wyższymi (ryc. 4). Wskaźnik ten wahał się od 69 do 385 i charakteryzował się dużym (choć nieco mniejszym niż w wyżej opisanym przypadku) zróżnicowaniem przestrzennym. Współczynnik zmienności wynosił 31,6\%. Rozkład tego wskaźnika wyraźnie wskazywał na znaczenie wielkich miast w kształtowaniu rozmieszczenia najlepiej wykształconej kadry. Można także stwierdzić, że obok wyżej wymienionych czynników (renta położenia, rozwój funkcji pozarolniczych) dwa przeciwstawne procesy powodowały ponadprzeciętne natężenia analizowanej grupy ludzi na obszarach sąsiadujących z największymi miastami. Po pierwsze, były to migracje ze wsi i małych miast do stref podmiejskich aglomeracji młodych, dobrze wykształconych ludzi w poszukiwaniu pracy i dobrych warunków życia. Po drugie, procesy gentryfikacji wiejskiej (rural gentrification por. Parsons 1980; Philips 1993; Heffner i Marszał 2011), w wyniku których bogata i równie dobrze wykształcona część mieszkańców miast zmieniała swoje miejsce zamieszkania na tereny wsi sąsiadujących z dużymi ośrodkami miejskimi. Obydwa procesy powodowały koncentrację na tych obszarach siły roboczej o najwyższych kwalifikacjach.

Na ryc. 4 wyraźnie widać, że ponadprzeciętne wartości wskaźnika wystąpiły w całej centralnej części Polski, rozciągając się koncentrycznie wokół największych miast oraz 
na Pobrzeżu Bałtyckim. Natomiast najniższe wartości zanotowano w woj. warmińsko-mazurskim, w południowej części woj. pomorskiego i zachodniopomorskiego, a więc na obszarach o dominujących funkcjach rolniczych, gdzie jeszcze przed rokiem 1989 funkcjonowały wielkoobszarowe państwowe gospodarstwa rolne. Mało zróżnicowana struktura funkcjonalna tych regionów przekłada się niekorzystnie na funkcjonowanie rynku pracy, a to nie sprzyjało napływowi absolwentów wyższych uczelni.

\section{Rozmieszczenie wiejskiej siły roboczej z wykształceniem średnim i policealnym w Polsce w 2011 r.}

W 2011 r. na obszarach wiejskich w Polsce średnio na 1000 osób w wieku produkcyjnym przypadało 294 z wykształceniem średnim i policealnym. Wskaźnik ten wahał się od 211 do 405. Współczynnik zmienności wynosił 12\%, co świadczyło o małym zróżnicowaniu przestrzennym. Wysoki wskaźnik (330 i więcej) zanotowano w 56 powiatach, tj. 17,8\% ich ogólnej liczby. Były to obszary sąsiadujące z największymi aglomeracjami miejsko-przemysłowymi kraju. Czynniki kształtujące ponadprzeciętną koncentrację tej grupy siły roboczej w wymienionych powiatach były analogiczne jak w przypadku osób z dyplomami wyższych uczelni (tab. 5, ryc. 5). Przeciętne wartości badanego wskaźnika charakteryzowały 109 powiatów (34,7\%). Były to obszary związane głównie z dawnymi miastami wojewódzkimi i powiatowymi (stan sprzed reformy 1999 r.). Funkcje administracyjne wykreowały popyt na średnio wykwalifikowaną kadrę, a dostępność szkół z wieczorowym systemem nauczania przyczyniła się do powstania dużej grupy ludności o tym poziomie kwalifikacji.

Tabela 5. Zróżnicowanie przestrzenne wiejskiej siły roboczej z wykształceniem średnim i policealnym w Polsce w $2011 \mathrm{r}$.

\begin{tabular}{|c|c|c|}
\hline $\begin{array}{l}\text { Wskaźnik: } \\
\text { liczba osób z wykształceniem } \\
\text { średnim i policealnym } \\
\text { na } 1000 \text { osób w wieku } \\
\text { produkcyjnym }\end{array}$ & $\begin{array}{l}\text { Liczba } \\
\text { powiatów }\end{array}$ & $\begin{array}{l}\text { Przykłady (pierwsze } 10 \text { z grupy) - w nawiasach wartość } \\
\text { wskaźnika }\end{array}$ \\
\hline $\begin{array}{l}\text { Wysoki } \\
\text { (330 i więcej) }\end{array}$ & 56 & $\begin{array}{l}\text { pruszkowski (411), olkuski (408), będziński (403), legionow- } \\
\text { ski (396), hajnowski (389), warszawski zachodni (388), rycki } \\
\text { (375), bieruńsko-lędziński (368), grodzisk (367), piaseczyński } \\
(366)\end{array}$ \\
\hline $\begin{array}{l}\text { Średni } \\
(294-329)\end{array}$ & 109 & $\begin{array}{l}\text { zgierski (329), brzeziński (329), tarnogórski (327), dzier- } \\
\text { żoniowski (327), jeleniogórski (236), białostocki (325), } \\
\text { przemyski (325), nowosądecki (235), namysłowski (325), } \\
\text { jędrzejowski (232) }\end{array}$ \\
\hline $\begin{array}{l}\text { Niski } \\
(258-293)\end{array}$ & 107 & $\begin{array}{l}\text { pleszewski (293), sanocki (293), pilski (293), bieszczadzki } \\
\text { (293), słupecki (293), suski (29), trzebnicki (292), leszczyński } \\
\text { (292), opatowski (292), łukowski (292) }\end{array}$ \\
\hline $\begin{array}{l}\text { Bardzo niski } \\
\text { (257 i mniej) }\end{array}$ & 42 & $\begin{array}{l}\text { strzelecko-drezdenecki (255), grudziądzki (25), wschowski } \\
\text { (255), złotowski (255), sławieński (254), sztumski (254), } \\
\text { szczecinecki (254), braniewski (254), drawski (254), rypiński } \\
\text { (253) }\end{array}$ \\
\hline Razem & 314 & $x$ \\
\hline
\end{tabular}

Źródło: Zestawienie własne na podstawie danych GUS. 


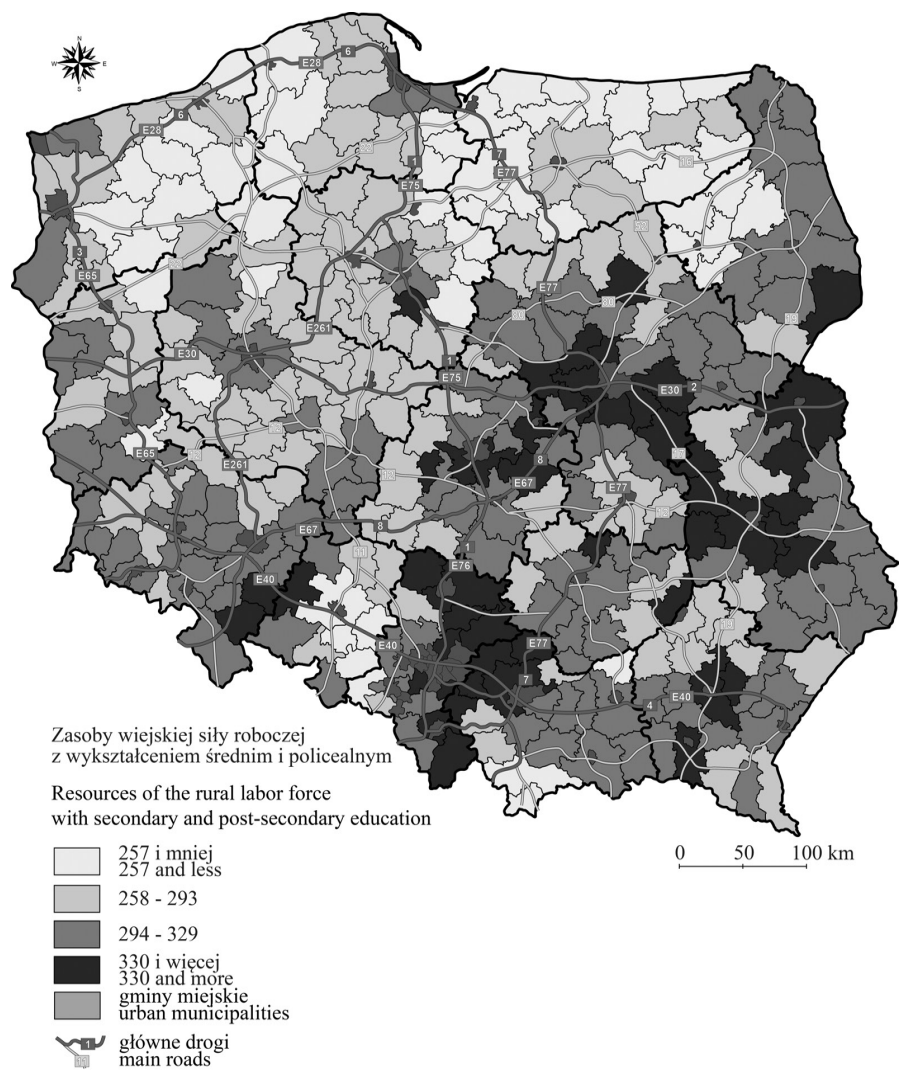

Ryc. 5. Liczba osób z wykształceniem średnim i policealnym na 1000 osób w wieku produkcyjnym na obszarach wiejskich w Polsce w 2011 r.

Number of people with secondary and post-secondary education per 1,000

people at working age in rural areas in Poland in 2011

Źródło/Source: opracowanie własne/own elaboration.

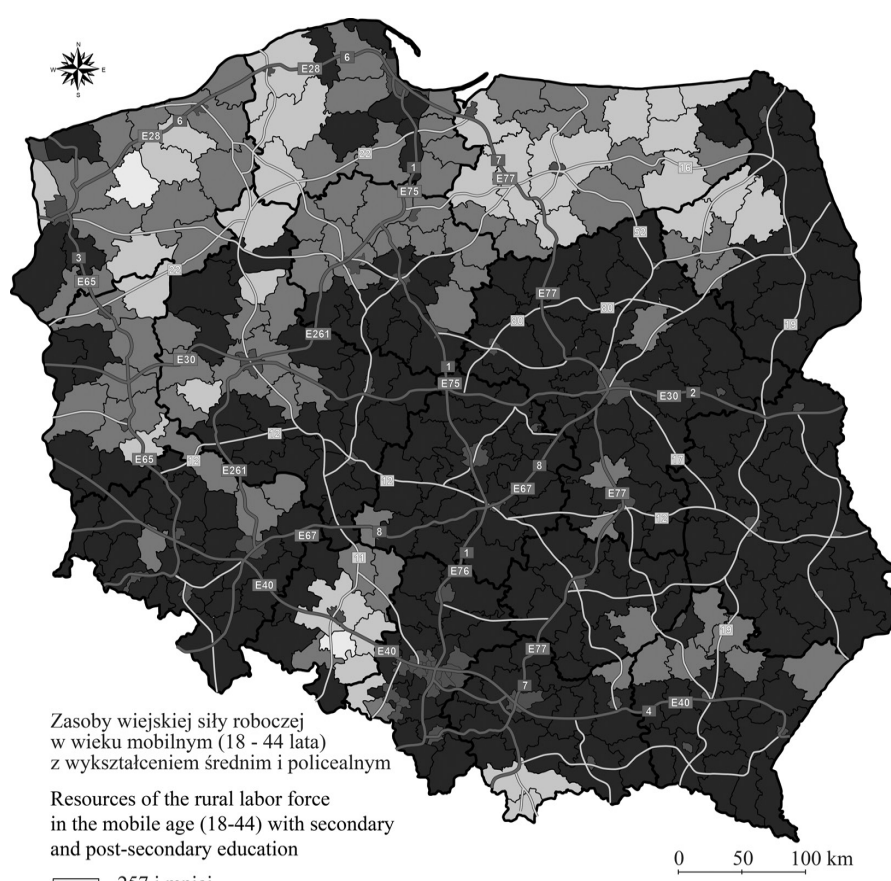

$\square$ 257 imniej

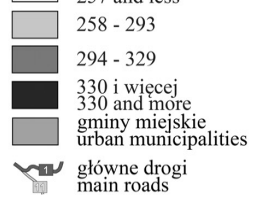

Ryc. 6. Liczba osób z wykształceniem średnim i policealnym w wieku mobilnym na 1000 osób w mobilnym wieku produkcyjnym na obszarach wiejskich w Polsce w $2011 \mathrm{r}$.

Number of people with secondary and post-secondary education per 1,000 people at mobile working age in rural areas in Poland in 2011 Źródło/Source: opracowanie własne/own elaboration. 
Niskie i bardzo niskie wartości wskaźnika (poniżej średniej dla polskiej wsi) wystąpiły łącznie w 149 powiatach (47,5\%). Skoncentrowane one były na obszarach woj. warmińsko-mazurskiego, zachodniopomorskiego, pomorskiego i podlaskiego, czyli na terenach, na których funkcjonowały PGR-y.

Rozkład przestrzenny tego wskaźnika nawiązywał do rozmieszczenia osób z wykształceniem wyższym (współczynnik korelacji 0,627) (ryc. 5). Jednak znaczenie dróg krajowych w przypadku dystrybucji siły roboczej legitymującej się dyplomem ukończenia edukacji na poziomie średnim i policealnym było większe niż w przypadku rozmieszczenia ludności po studiach. Szczególnie dobrze było to widoczne wzdłuż drogi: Warszawa-Lublin. Na całym odcinku rozciągały się obszary o wysokich wskaźnikach obrazujących liczbę osób z wykształceniem średnim i policealnym na 1000 ludności w wieku produkcyjnym. Na uwagę zasługują także niskie wskaźniki w Wielkopolsce, gdzie młodzież niechętnie podejmowała naukę w niedających konkretnego zawodu liceach ogólnokształcących. Obszary rolnicze, zwłaszcza związane z rolnictwem wielkoobszarowym, cechowały się niską (niższą od średniej) koncentracją osób o analizowanym poziomie edukacji.

Zdecydowanie lepiej przedstawiała się reprezentacja osób posiadających dyplom ukończenia szkoły średniej wśród zasobów mobilnej siły roboczej. Średnio na 1000 osób do 44 roku życia przypadało 346 ze świadectwem szkoły średniej. Rozpiętość między minimalną wartością (247) a maksymalną (458) wynosiła 211, a współczynnik zmienności kształtował się na poziomie $12 \%$. W układzie przestrzennym tego wskaźnika wyraźnie widać podział na Polskę centralną oraz południowo-wschodnią, gdzie występowały ponadprzeciętne wartości wskaźnika oraz na Polskę zachodnią i północną o zdecydowanym niedoborze tej grupy potencjalnych pracowników (ryc. 6). W centralnej i południowo-wschodniej części kraju wysokie natężenie osób z wykształceniem średnim było wypadkową procesów industrializacji i urbanizacji wsi w okresie gospodarki centralnie sterowanej oraz dostępności szkół i wzroście aspiracji młodzieży wiejskiej współcześnie. Rozwój okręgów przemysłowych (warszawskiego, łódzkiego, staropolskiego, centralnego, górnośląskiego) i funkcji pozarolniczych stworzył popyt na wykształconą kadrę, której dzieci powielały drogę edukacyjną swoich rodziców. Badania wykazały, że tam gdzie wskaźniki struktury wykształcenia były korzystne w gospodarce centralnie sterowanej, odnotowano nadreprezentację osób najlepiej wykształconych w późniejszych okresach (Kamińska 2014). W układzie przestrzennym także wyraźnie widać wpływ regionalnych i krajowych ośrodków miejskich na strukturę wykształcenia ludności. Im większe miasto tym strefa obszarów z korzystnym odsetkiem mieszkańców dobrze wyedukowanych była większa. Należy jednak podkreślić, że nawet na obszarach popegeerowskich wskaźniki przedstawiające liczbę osób z ukończoną szkołą średnią w wieku mobilnym na 1000 osób w wieku do 44 roku życia były zdecydowanie wyższe, aniżeli liczone dla całej populacji zasobów siły roboczej.

Warto jeszcze zwrócić uwagę, że inne czynniki wywołały niski udział siły roboczej o średnim wykształceniu na obszarach Polski północnej (obszary popegeerowskie), a inne w Wielkopolsce. W tym ostatnim regionie zanotowano nadreprezentację osób z ukończonymi szkołami zawodowymi, a w Polsce północnej z wykształceniem podstawowym (por. Kamińska 2014). 


\section{Rozmieszczenie wiejskiej siły roboczej z wykształceniem zasadniczym zawodowym w Polsce w 2011 r.}

W 2011 r. na obszarach wiejskich w Polsce średnio na 1000 osób w wieku produkcyjnym przypadało 308 z wykształceniem zasadniczym zawodowym. W poszczególnych powiatach wskaźnik ten wahał się od 135 do 439 i nie był bardzo zróżnicowany w układzie przestrzennym. Współczynnik zmienności wynosił 15\%. Wysoką liczbę osób z wykształceniem zasadniczym zawodowym w stosunku do ogółu zasobów siły roboczej (356 i więcej) zanotowano w 45 jednostkach przestrzennych (14,3\%). Były one głównie skoncentrowane w województwie wielkopolskim i pomorskim (tab. 6, ryc. 7).

Tabela 6. Zróżnicowanie przestrzenne wiejskiej siły roboczej z wykształceniem zasadniczym zawodowym w Polsce w $2011 \mathrm{r}$.

\begin{tabular}{|c|c|c|}
\hline $\begin{array}{l}\text { Wskaźnik: } \\
\text { liczba osób z wykształceniem } \\
\text { zasadniczym zawodowym } \\
\text { na } 1000 \text { osób w wieku } \\
\text { produkcyjnym }\end{array}$ & $\begin{array}{l}\text { Liczba } \\
\text { powiatów }\end{array}$ & $\begin{array}{l}\text { Przykłady (pierwsze } 10 \text { z grupy) - w nawiasach wartość } \\
\text { wskaźnika }\end{array}$ \\
\hline $\begin{array}{l}\text { Wysoki } \\
\text { (356 i więcej) }\end{array}$ & 45 & $\begin{array}{l}\text { grodziski (439), nowotomyski (422), rawicki (420), krotoszyń- } \\
\text { ski (415), ostrowski (405), chodzieski (405), kępiński (404), } \\
\text { kościański (404), wadowicki (396), leszczyński (391) }\end{array}$ \\
\hline $\begin{array}{l}\text { Średni } \\
(308-355)\end{array}$ & 101 & $\begin{array}{l}\text { mławski (353), prudnicki (35), górowski (351), lubliniecki } \\
\text { (350), raciborski (350), słupecki (349), lubański (348), gorlicki } \\
\text { (347), nyski (347), strzelecki (346), }\end{array}$ \\
\hline $\begin{array}{l}\text { Niski } \\
(260-307)\end{array}$ & 117 & $\begin{array}{l}\text { strzeliński (307), jaworski (37), opoczyński (307), lipski (306), } \\
\text { pułtuski (306), białogardzki (306), oławski (305), płocki (305), } \\
\text { kaliski (305), działdowski (305) }\end{array}$ \\
\hline $\begin{array}{l}\text { Bardzo niski } \\
\text { (259 i mniej) }\end{array}$ & 51 & $\begin{array}{l}\text { giżycki (259), olkuski (258), krasnostawski (28), lubelski (257), } \\
\text { parczewski (254), wysokomazowiecki (254), będziński (253), } \\
\text { poznański (249, zgierski (248), leski (247) }\end{array}$ \\
\hline Razem & 314 & $x$ \\
\hline
\end{tabular}

Źródło: Zestawienie własne na podstawie danych GUS.

Przeciętne wartości (308-355) analizowany wskaźnik osiągnął w 101 powiatach (32,2\%). Te obszary ciągnęły się zwartym pasem od woj. pomorskiego przez wielkopolskie, dolnośląskie, opolskie, śląskie po małopolskie, tworząc charakterystyczną literę „'””. Obszary te nawiązywały do najbardziej uprzemysłowionych terenów w okresie gospodarki centralnie sterowanej (por. Fierla 1979). Ekstensywny rozwój przemysłu, oparty głównie na zasobach słabo wykwalifikowanej siły roboczej, generował popyt na robotników z wykształceniem zasadniczym zawodowym. Niskie i bardzo niskie wartości wskaźnika (poniżej 307) zanotowano w 168 powiatach (53,5\%). Rozciągały się one przede wszystkim na obszarach wschodniej Polski (na wschód od Wisły i nawiązywały do obszarów rolniczych.

Wśród zasobów mobilnej siły roboczej wykształcenie zasadnicze zawodowe cieszyło się mniejszą popularnością. Wskaźnik przedstawiający liczbę osób z tym poziomem wykształcenia w ogólnej liczbie osób w wieku mobilnym wynosił 208 (o 100 mniej niż w całych zasobach siły roboczej) i wahał się od 94 do 441 . W tym przypadku zdecydowanie widać podział kraju na wschodnią część o niskich wskaźnikach i zachodnią o ponadprzeciętnym stosunku liczby robotników po zawodówkach do ogółu osób w wieku mobilnym. Jednak należy podkreślić, że strefa bardzo wysokich wartości wskaźnika wokół Poznania widocznie zmniejszyła się (ryc. 8). 


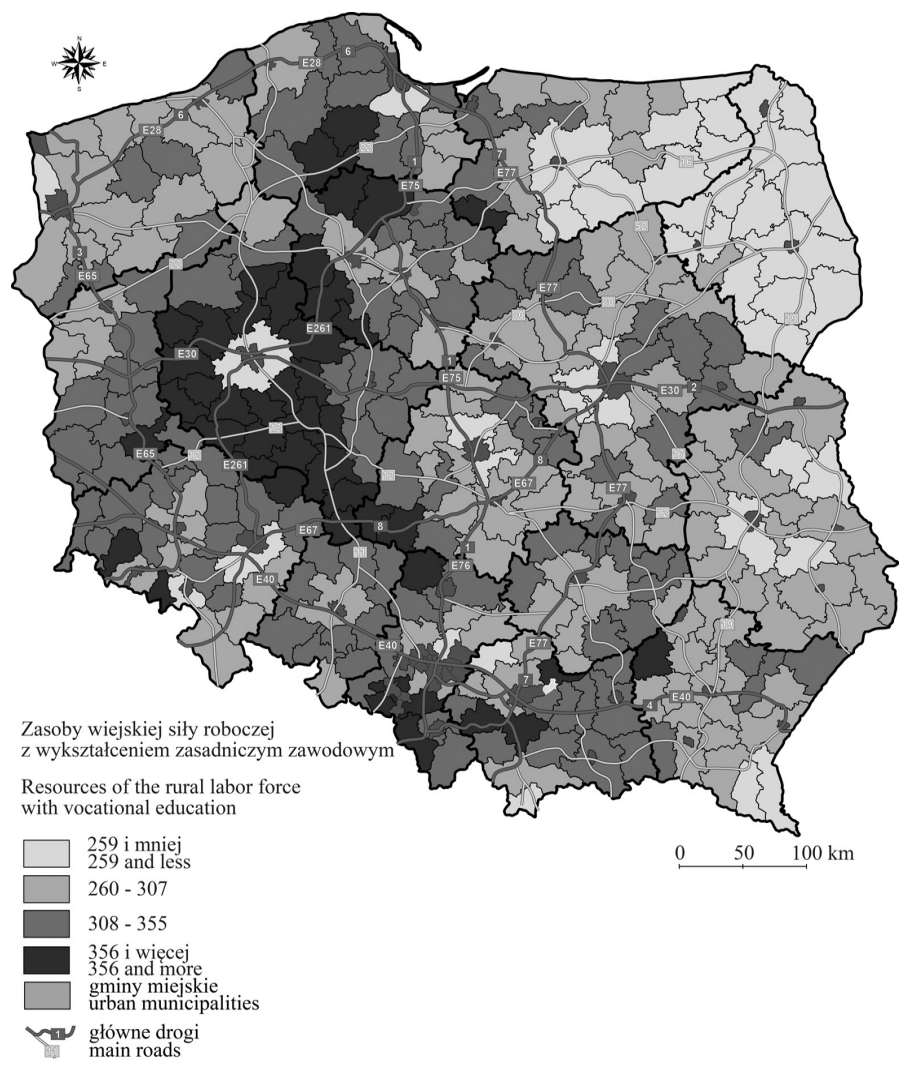

Ryc. 7. Liczba osób z wykształceniem zasadniczym zawodowym na 1000 osób w wieku produkcyjnym na obszarach wiejskich w Polsce w 2011 r.

Number of people with vocational education per 1,000 people at working age in rural areas in Poland in 2011

Źródło/Source: opracowanie własne / own elaboration

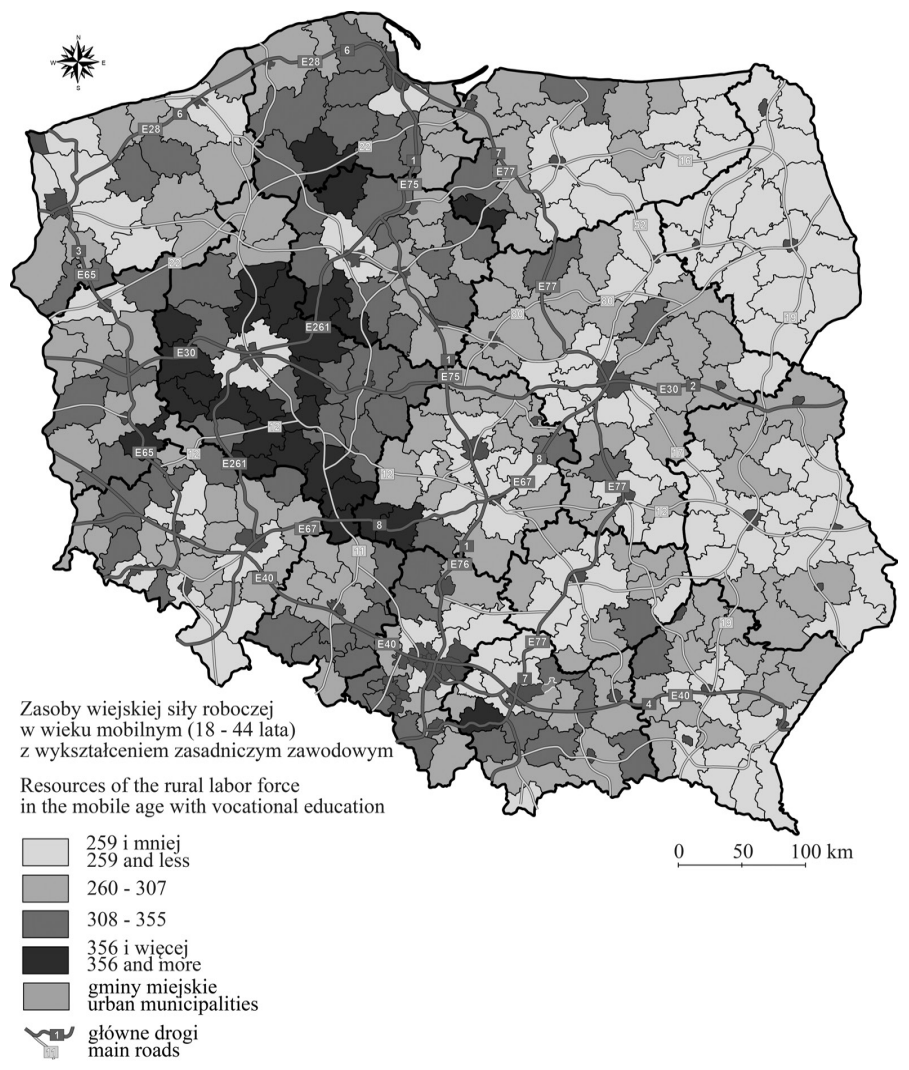

Ryc. 8. Liczba osób z wykształceniem zasadniczym zawodowym w wieku

mobilnym na 1000 osób w mobilnym wieku produkcyjnym na obszarach wiejskich w Polsce w $2011 \mathrm{r}$.

Number of people with vocational education per 1,000 people at mobile

working age in rural areas in Poland in 2011

Źródło/Source: opracowanie własne / own elaboration 
Rozkład przestrzenny tego wskaźnika nawiązywał do zasięgu zaborów (XIX w.). Na obszarze zaboru rosyjskiego odsetek osób posiadających konkretny zawód kształtował się na ogół poniżej średniej dla polskiej wsi, tereny zaboru austriackiego cechowały się przeciętnymi wartościami badanego wskaźnika. Natomiast ponadprzeciętny procent osób z wykształceniem zawodowym zanotowano w obrębie zaboru pruskiego. Wyjątek stanowiły województwa zachodniopomorskie i warmińsko-mazurskie. Niski udział ludności po szkołach zawodowych był związany z procesami zasiedlania (po II wojnie światowej) tych rejonów przez ludność z obszarów wschodnich, a więc ludność o specyficznej (wschodniej, mało przedsiębiorczej) mentalności (por. Szpak 2013; Szafraniec 2015). Oznacza to, że opisywane różnice w poszczególnych zaborach i ich konsekwencje nie zostały zniwelowane w okresie gospodarki centralnie sterowanej, a wręcz przeciwnie - zostały utrwalone, a czasami nawet wzmocnione.

\section{Rozmieszczenie wiejskiej siły roboczej z wykształceniem gimnazjalnym i podstawowym w Polsce w 2011 r.}

W 2011 r. na obszarach wiejskich Polski średnio na 1000 osób w wieku produkcyjnym przypadało 249 osób odznaczających się najniższym poziomem kwalifikacji formalnych. W poszczególnych powiatach analizowany wskaźnik wahał się od 125 do 402 i był znacznie zróżnicowany przestrzennie. Współczynnik zmienności wynosił 21\%. Wysokie wskaźniki obrazujące liczbę osób z najniższym poziomem wykształcenia szkolnego na 1000 osób w wieku produkcyjnym zanotowano w 48 powiatach (15,3\%). Prawie wszystkie położone były w Polsce północnej, w województwie warmińsko-mazurskim, zachodniopomorskim, podlaskim i kujawsko-pomorskim, czyli na obszarach, na których funkcjonowały wielkoobszarowe PGR. Średni wskaźnik wystąpił w 100 powiatach (31,8\%), które w Polsce północnej sąsiadowały z jednostkami cechującymi się ponadprzeciętnymi wartościami tego wskaźnikami. Nadto duża część tych obszarów skoncentrowana była w północnej części województwa mazowieckiego, wzdłuż wschodniej i zachodniej granicy kraju oraz na pograniczu województw świętokrzyskiego, łódzkiego i mazowieckiego. Natomiast niska i bardzo niska liczba osób z ukończoną tylko podstawówką i gimnazjum wystąpiła w 166 powiatach (52,9\%), na terenie których dobrze rozwinięte były funkcje pozarolnicze.

W rozkładzie przestrzennym analizowanego wskaźnika widać, że najwyższe jego wartości wystąpiły na obszarach Polski północno-wschodniej oraz północno-zachodniej, gdzie funkcjonujące w XX w. państwowe gospodarstwa rolne stworzyły miejsca pracy dla niewykwalifikowanej siły roboczej (ryc. 9). Brak (lub mała liczba) alternatywnych (pozarolniczych) źródeł utrzymania wpływała na utrwalenie się niekorzystnej struktury wykształcenia zasobów siły roboczej tych terenów. Trwałość tych deformacji była na tyle duża, że nawet nowe warunki gospodarowania, nowe możliwości kształcenia się nie były istotnym impulsem do podnoszenia kwalifikacji. Było to na pewno związane z możliwościami finansowymi, ale także z mentalnością mieszkańców tych obszarów (por. Szpak 2013). Istotny był także fakt, że najniższy poziom wykształcenia posiadała głównie ludność w niemobilnym (starszym) wieku produkcyjnym, co może stanowić dobrą stronę zaistniałej sytuacji. Jednak należy podkreślić, że niewykształceni rodzice mają wpływ na przebieg nauki swoich dzieci (Herbst 2004; Śleszyński 2004), a to może w dalszym ciągu utrwalać niekorzystną strukturę wykształcenia na tych terenach. 
Tabela 7. Zróżnicowanie przestrzenne wiejskiej siły roboczej z wykształceniem gimnazjalnym i podstawowym w Polsce w 2011 r.

\begin{tabular}{|l|c|l|}
\hline $\begin{array}{l}\text { Wskaźnik: } \\
\text { liczba osób z wykształce- } \\
\text { niem gimnazjalnym i pod- } \\
\text { stawowym na } \mathbf{1 0 0 0} \text { osób } \\
\text { w wieku produkcyjnym }\end{array}$ & $\begin{array}{l}\text { Liczba } \\
\text { powiatów }\end{array}$ & $\begin{array}{l}\text { Przykłady (pierwsze } \mathbf{1 0} \text { z grupy) - w nawiasach wartość } \\
\text { wskaźnika }\end{array}$ \\
\hline $\begin{array}{l}\text { Wysoki } \\
\text { (303 i więcej) }\end{array}$ & 48 & $\begin{array}{l}\text { piski (402), kolneński (395), nidzicki (383), rypiński (382), bia- } \\
\text { łogardzki (379, łobeski (376), choszczeński (376), olecki (368), } \\
\text { iławski (357), ostródzki (354) }\end{array}$ \\
\hline $\begin{array}{l}\text { Średni } \\
(249-302)\end{array}$ & 100 & $\begin{array}{l}\text { sławieński (302), goleniowski (32), stargardzki (301), bieszczadzki } \\
\text { (31), kolski (2999), malborski (299), myśliborski (299), sierpecki } \\
\text { 9297), kwidzyński (297) nowotarski (296) }\end{array}$ \\
\hline $\begin{array}{l}\text { Niski } \\
(195-248)\end{array}$ & 121 & $\begin{array}{l}\text { krośnieński (248), kielecki (248), grodziski (247), świecki (247), } \\
\text { tczewski (246), złotoryjski (246), pucki (246), jarosławski (246), } \\
\text { bialski (245), nowosolski (245) }\end{array}$ \\
\hline $\begin{array}{l}\text { Bardzo niski } \\
(194 \text { i mniej) }\end{array}$ & 45 & $\begin{array}{l}\text { kępiński (192), wadowicki (192), ostrowski (190), oleski (190), } \\
\text { tarnowski (190), rzeszowski (190), otwocki (188), prudnicki (187), } \\
\text { skarżyski (187), grodziski (187). }\end{array}$ \\
\hline Razem & 314 & \multicolumn{2}{c}{ x } \\
\hline
\end{tabular}

Źródło: Zestawienie własne na podstawie danych GUS.

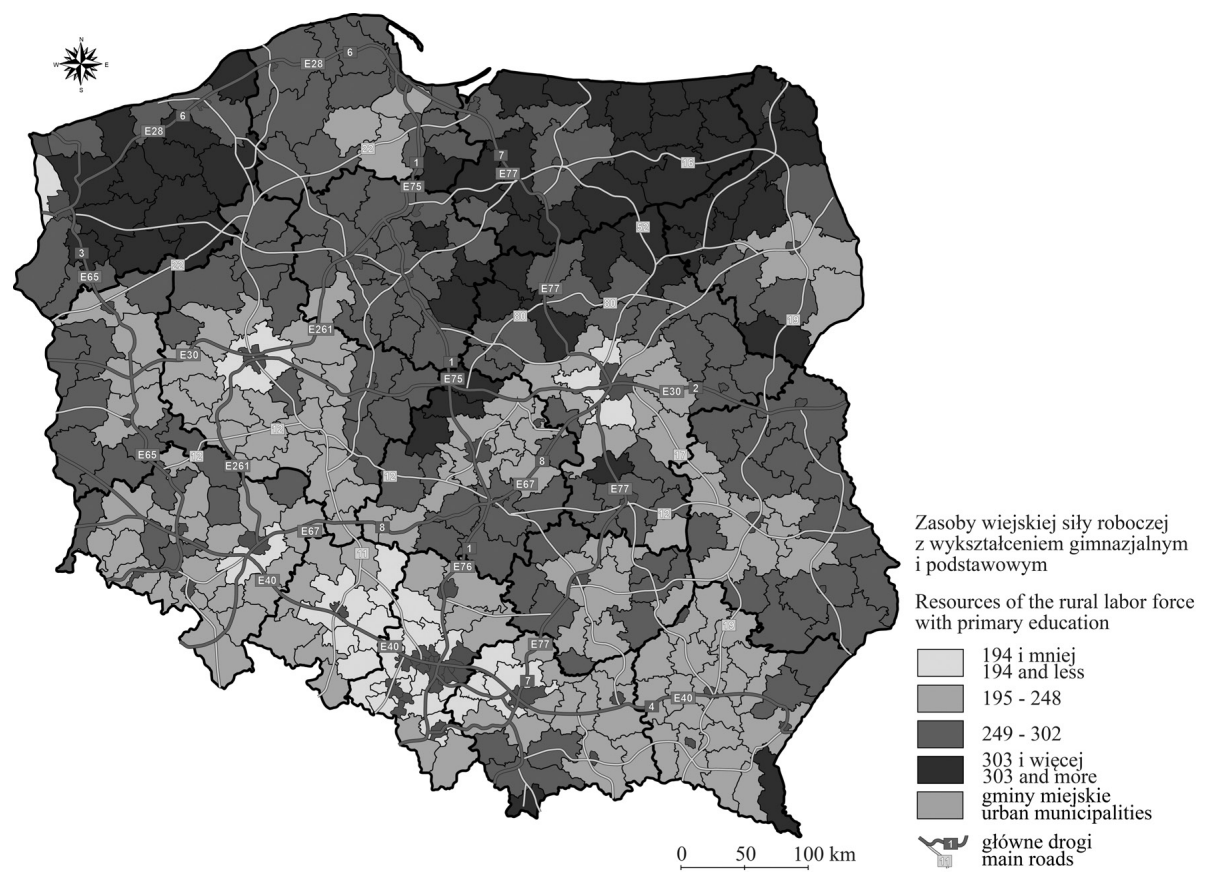

Ryc. 9. Liczba osób z wykształceniem gimnazjalnym i podstawowym na 1000 osób w wieku produkcyjnym na obszarach wiejskich w Polsce w 2011 r.

Number of people with primary education per 1,000 people of working age in rural areas in Poland in 2011 Źródło/Source: opracowanie własne/own elaboration. 


\section{Podsumowanie}

Z powyższych badań wynika, że poziom wykształcenia siły roboczej na wsi był niższy niż w miastach i kraju ogółem, ale w stosunku do 2002 r. uległ zdecydowanej poprawie. Wzrost odsetka ludności wiejskiej z wykształceniem średnim i wyższym należy ocenić pozytywnie, ale nie wolno zapominać, że dystans między miastem a wsią pod tym względem był bardzo duży. Średnio co ósmy mieszkaniec wsi i co czwarty miast (w wieku produkcyjnym) legitymował się dyplomem wyższej uczelni. Oznacza to, że w miastach wskaźnik ten był dwa razy wyższy niż na obszarach wiejskich, a jak wskazują badania, to właśnie absolwenci szkół wyższych są najlepiej przygotowani do kreowania i stosowania innowacyjnych rozwiązań w gospodarce kraju. Duży dystans w zakresie najwyżej wykwalifikowanych zasobów siły roboczej dotyczył także młodego pokolenia. Co siódmy człowiek do 44 roku życia zameldowany na wsi był absolwentem wyższej uczelni. Wśród miejskiej siły roboczej wskaźnik ten był znacznie korzystniejszy, bowiem prawie co trzecia osoba w wieku mobilnym ukończyła studia. Absolwenci szkół średnich i policealnych na wsi stanowili $30 \%$ wiejskich zasobów pracowniczych - w miastach ponad 38\%. W przypadku mobilnej siły roboczej udział procentowy osób, które ukończyły edukację na poziomie średnim, był o ok. 5 p.p. wyższy w miastach niż na wsi.

Powyższe wskaźniki powinno się rozpatrywać również w układzie przestrzennym. Znamienna była duża reprezentacja tych grup ludności w strefach podmiejskich wielkich aglomeracji i znaczny ich niedobór na obszarach peryferyjnych. Bliskość miast i funkcje pozarolnicze były czynnikami sprzyjającymi kumulacji najlepiej wykształconej kadry, natomiast tereny odległe od szlaków komunikacyjnych i zróżnicowanych miejskich rynków pracy były obszarami „wymywania” (odpływu) kapitału ludzkiego o wysokiej jakości. Nasuwa się pytanie, czy taki rozkład zasobów siły roboczej jest korzystny dla gospodarki wymienionych terenów? Odpowiedź nie jest tak jednoznaczna, jakby mogło się wydawać. Można jednak przedstawić pewien punkt widzenia, który z natury rzeczy będzie dyskusyjny.

Zacznę od obszarów podmiejskich. W literaturze przedmiotu przyjmuje się, że wysokie wykształcenie sprzyja uzyskiwaniu ponadprzeciętnych dochodów indywidualnych i jest ważnym czynnikiem bogacenia się jednostek przestrzennych (por. np. Jimenez i in. 2012). Teza ta jest prawdziwa wtedy, gdy wysokiej jakości kapitału ludzkiego towarzyszy wysoki poziom kapitału społecznego (por. Woolcock i Narayan 2000; Kamińska 2011a). Trudno taką prawidłowość potwierdzić na obszarach podmiejskich aglomeracji. Tereny te są zwykle objęte napływem ludności ze wsi (migracje) oraz z wielkich miast (gentryfikacja wiejska). Korzyści i niekorzyści procesów gentryfikacji zostały opisane w literaturze światowej (por. np. Spain 1992; Atkison 2003; Slater i in. 2004) i polskiej (por. np. Grzeszczak 2010; Wójcik 2014). Autorzy podkreślali, że gentryfikacja często wpływa niekorzystnie na objęte nią tereny, zwłaszcza na spójność oraz tożsamość lokalnych społeczności i stanowi podłoże konfliktów w ich obrębie (Spain 1992). Konflikty te powstają, z jednej strony na tle ekonomicznie uwarunkowanych różnic w dostępie do miejscowych zasobów, w tym mieszkaniowych, z drugiej zaś na tle różnic w dziedzinie wyznawanych wartości (Grzeszczak 2010). Gentryfikatorzy zwykle związani są z wsią tylko poprzez miejsce zamieszkania; pracują, tworzą swoje firmy i płacą od nich podatki w miastach (por. Heffner 2015). Ludność nowo napływająca ze wsi peryferyjnie położonych także z trudem nawiązuje więzi społeczne z tubylcami (por. Wójcik 2014; Kamińska 2011a). Nie są to czynniki budujące kapitał społeczny. Z drugiej strony migrują zwykle osoby aktywne zawodowo i społecznie, 
często posiadające własny kapitał, który nierzadko inwestują na nowo zasiedlanych terenach. Wzrost populacji przekłada się na wzrost popytu na towary oraz usługi i daje asumpt do tworzenia pozarolniczych podmiotów gospodarczych. Rozwój przedsiębiorczości oraz wysokie dochody samorządów terytorialnych na obszarach podmiejskich świadczą jednak o ich sukcesach gospodarczych (por. Kamińska 2011b).

Z kolei na obszarach peryferyjnych, w tym rolniczych (por. Hrušek 2015), stosunek wielkości najwyżej wykształconej siły roboczej do jej ogólnych zasobów był niski. Jeśli przyjmiemy tezę, że to funkcje pozarolnicze kreowały popyt na siłę roboczą o wysokich kwalifikacjach, to można przyjąć, że na tych obszarach było mniejsze zapotrzebowanie na pracowników po studiach, bo te działy gospodarki były słabiej rozwinięte niż w strefach podmiejskich. Ważny natomiast był poziom wykształcenia pozostałych zasobów siły roboczej; czy w strukturze tych obszarów dominowały osoby z wykształceniem zasadniczym zawodowym czy zaledwie podstawowym? Niniejsze badania wykazały, że na obszarach rolniczych Polski zachodniej odnotowano ponadprzeciętne wskaźniki obrazujące zasoby siły roboczej z wykształceniem zawodowym, a w Polsce wschodniej z podstawowym. Najniższy poziom kwalifikacji formalnych nie jest zazwyczaj czynnikiem pobudzającym aktywność zawodową i przedsiębiorczość, ale raczej ograniczającym możliwość znalezienia pracy, wpływającym na wykluczenie społeczne oraz obniżanie się poziomu i jakości życia ludności. Z kolei osoby z wykształceniem zasadniczym zawodowym teoretycznie mogły mieć większy wachlarz możliwości na rynku pracy, mając jednocześnie predyspozycje zawodowe do założenia własnej firmy produkcyjnej lub usługowej. Tezę tę potwierdzały wysokie wskaźniki przedsiębiorczości na obszarach wiejskich zachodniej Polski, które korespondowały z ponadprzeciętnymi udziałami osób po „zawodówkach” w strukturze wykształcenia siły roboczej (por. Kamińska 2011b).

Pozytywnie należy ocenić fakt, że młoda część siły roboczej na wsi częściej podnosiła swoje szkolne wykształcenie. Edukację na poziomie tylko elementarnym zakończyło 16\% mieszkańców wsi do 44 roku życia, przy analogicznym wskaźniku dla całych wiejskich zasobów pracowniczych na poziomie 19,5\%. Niestety coraz mniej osób w mobilnym wieku produkcyjnym na wsi kończyło szkoły zawodowe. Wiejskie zasoby pracowników do 44 roku życia z tym poziomem edukacji stanowiły 25\%, podczas gdy analogiczny wskaźnik liczony dla całości ludności w wieku produkcyjnym wynosił prawie 31\%. Szczególnie wysoki niedobór pracowników po zawodówkach, w stosunku do zasobów siły roboczej, wystąpił w Polsce wschodniej co było wyjątkowo niekorzystne. Słabo rozwinięta gospodarka innowacyjna na tych terenach, postępujący wielofunkcyjny rozwój wsi oraz wysokie bezrobocie (Strategia rozwoju... 2013) powinny stymulować konieczność uzyskiwania konkretnego zawodu.

Badania potwierdziły także, że rolnictwo, zwłaszcza na obszarach z dominacją (w przeszłości) państwowych gospodarstw rolnych, utrwaliło niekorzystną strukturę wykształcenia zasobów siły roboczej (na tych terenach zaobserwowano najwyższy odsetek osób o najniższych formalnych kwalifikacjach).

W pracy przedstawiono ilościową stronę struktury wykształcenia ludności wiejskiej. Pominięto jakościowe aspekty ze względu na brak danych. 


\section{Literatura}

Acemoglu D., 1996, Microfoundation for Social Increasing Returns in Human Capital Accumulation, Quarterly Journal of Economics, 111 (3), s. 779-804.

Arandarenko M., Bartlett W., (red.), 2012, Labour Market and Skills in the Western Balkans, FREN \& LSEE, Belgrad.

Arrow K., 1962, The Economic Implications of Learning by Doing, Review of Economic School Studies, 29, s. 155-173.

Atkinson R., 2003, Introduction. Misunderstood Saviour or Vengeful Wrecker? The Many Meanings and Problems of Gentrification, Urban Studies, 40, 12, s. 2343-2350.

Autor D.H., Levy F., Murnane R., 2003, The Skill Content of Recent Technological Change: An Empirical Exploration, Quarterly Journal of Economics, 118, 4, s. 1279-1333.

Baran E., 2011, Wiejskie obszary depopulacji w Polsce. Przykład Polski Południowo-Wschodniej, [w:] W. Kamińska, K. Heffner (red.), Obszary wiejskie: wielofunkcyjność, migracje, nowe wizje rozwoju, Studia KPZK PAN, 133, Warszawa, s. 197-213.

Bartlett W., 2013, Skill Mismatch, Education Systems, and Labour Markets in EU Neighbourhood Policy Countries, Search Working Paper, 20.

Barro R.J., Lee J.W., 1996, International Measures of Schooling Years and Schooling Quality, American Economic Review Papers and Proceedings, 86, s. 218-223.

Becker G.S., 1964, Human Capital: A Theoretical and Empirical Analysis with Special Reference to Education, The University of Chicago Press, Chicago.

Berman E., Bound J., Griliches Z., 1994, Changes in the Demand for Skilled Labor within U. S. Manufacturing Industries: Evidence from the Annual Survey of Manufacturers, Quarterly Journal of Economics, 109, s. 67-397.

Berman E., Bound J., Machin S., 1998, Implications of Skill-Biased Technological Change: International Evidence, Quarterly Journal of Economics, 113, s. 1245-1279.

Bresnahan T.F., Brynjolfsson E., Hitt L.M., 2002, Information Technology, Workplace Organization and the Demand for Skilled Labor: Firm-Level Evidence, Quarterly Journal of Economics, 117, s. 339-376.

Caselli F., Esquivel G., Lefort F., 1996, Reopening the Convergence Debate: A New Look at CrossCountry Growth Empirics, Journal of Economic Growth, Springer, 1 (3), s. 363-389.

Ciok S., Ilnicki D., 2012, Demograficzne i przestrzenne uwarunkowania rynku pracy na wsi dolnośląskiej, [w:] W. Kamińska, K. Heffner (red), Wiejskie rynki pracy - zasoby, aktywizacja, nowe struktury, Studia KPZK PAN, 145, Warszawa, s. 142-162.

De Barros R.P., Ferreira F.H.G., Vega J.R.M., Chanduvi J.S., 2009, Measuring Inequality of Opportunities in Latin America and the Caribbean, World Bank, Washington.

De la Fuente A., Ciccone A., 2003, Human Capital in a Global and Knowledge-Based Economy, UFAE and IAE Working Papers 562.03, Unitat de Fonaments de I'Anàlisi Econòmica (UAB) and Institut d'Anàlisi Econòmica (CSIC).

Denison E.F., 1971, Education, Economic Growth, and Gaps in Information, [w:] R. A. Wykstra (red.), Education and the Economics of Human Capital, Collier-Macmillan, London, s. 124-128.

Denny K., O’Sullivan V., 2007, Can Education Compensate for Low Ability?: Evidence From The British Data, Applied Economics Letters, 14, 9, s. 657-660.

Fierla I., 1979, Geografia przemysłu Polski, PWE, Warszawa.

Freeman R.B., 1986, Demand for Education, [w:] O. Ashenfelter, R. Layard (red.), Handbook of Labour Economics, 1, Elsevier, New York, s. 357-386. 
Grzeszczak J., 2010, Gentryfikacja osadnictwa - charakterystyka, rozwój koncepcji badawczej i przegląd wyjaśnień, Monografie IGiPZ PAN, 11, Warszawa.

Hanushek E.A., Woessmann L., 2008, The Role of Cognitive Skills in Economic Development, Journal of Economic Literature, 46, 3, s. 607-668.

Heffner K., 2015, Zmiany przestrzenne na obszarach wiejskich w Polsce w okresie 2004-2014 i do 2020 roku, referat wygłoszony na XXXI Seminarium Geografii Wsi-Obszary wiejskie - pierwsza dekada w Unii Europejskiej i nowa perspektywa, Opole, 27 kwietnia 2015 r.

Heffner K., Marszał T., (red.), 2011, Rewitalizacja, gentryfikacja i problemy rozwoju małych miast, Studia KPZK PAN, 136, Warszawa.

Herbst M., 2004, Zróżnicowanie jakości kapitału ludzkiego w Polsce. Od czego zależq wyniki edukacyjne, Studia Regionalne i Lokalne, 3 (17), s. 89-104.

Heston A., Summers R., Aten B., 2002, Penn World, Table Version 6.1, Center for International Comparisons at the University of Pensylwania (CICUP).

Hrušek V., (red.), 2015, Post-Agricultural Rural Space of the Visegrad Countries: Economies, Entrepreneurship and Policies, Studia Obszarów Wiejskich, 39.

Janc K., Czapiewski K., 2005, Wykształcenie czynnikiem wspierającym rozwój gospodarczy obszarów wiejskich, Studia Obszarów Wiejskich, 8, s. 69-84.

Jimenez E., Nguyen V., Patrinos H.A., 2012, Stock in the Middle? Human Capital Development and Economic Growth in Malaysia and Thailand Policy Research Working Papers, 6283, The World Bank Human Development Network Education Unit.

Kacprzak E., 2010, Przestrzenne zróżnicowanie kapitału ludzkiego i społecznego na obszarach wiejskich woj. wielkopolskiego, [w:] W. Kamińska, K. Heffner (red), Kapitał ludzki i społeczny w procesie rozwoju obszarów wiejskich, Studia KPZK PAN, 126, Warszawa, s. 161-180.

Kamińska W., 2011a, Kapitał ludzki i społeczny na obszarach wiejskich w Polsce. Przykład województwa świętokrzyskiego, IG UJK, Kielce.

Kamińska W., 2011b, Aktywność gospodarcza osób fizycznych na obszarach wiejskich w Polsce, [w:] W. Kamińska, K. Heffner, (red.), Obszary wiejskie: wielofunkcyjność, migracje, nowe wizje rozwoju, Studia KPZK PAN, 133, Warszawa, s. 103-127.

Kamińska W., 2014, Przemiany struktury i poziomu wykształcenia ludności wiejskiej w Polsce w latach 2002-2011, [w:] W. Kamińska, K. Heffner (red.), Polityka spójności UE a rozwój obszarów wiejskich: stare problemy i nowe wyzwania, Studia KPZK PAN, 154, Warszawa, s. 129-167.

Kamińska W., Heffner K., (red.), 2012, Wiejskie rynki pracy - zasoby, aktywizacji, nowe struktury, Studia KPZK PAN, 145, Warszawa.

Karoly L.A., 2010, The Role of Education in Preparing Graduates for the Labor Market in the GCC Countries, Working Paper, Rand, Arlington.

Karoly L.A., Panis C.W.A., 2004, The 21st Century at Work: Forces Shaping the Future Workforce and Workplace in the United States, MG-164, The RAND Corporation, Santa Monica, California.

Kendrick J.W., 1961, Productivity Trends in the United States, A Study by the National Bureau of Economic Research, Princeton University Press, New York.

Kirchhoff B.A., Newbert S.L., Hasan I., Armington C., 2007, The Influence of University R\&D Expenditures on New Business Formations and Employment Growth, Entrepreneurship Theory and Practice, July, s. 543-559.

Komornicki T., Czapiewski K., 2010, Dostępność przestrzenna do ośrodków akademickich a poziom kapitału ludzkiego na obszarach wiejskich Mazowsza, [w:] W. Kamińska, K. Heffner, (red.), Kapitał ludzki i społeczny w procesie rozwoju obszarów wiejskich, Studia KPZK PAN, 126, Warszawa, s. 66-85. 
Kulikowski R., 2002, Problemy społeczne wsi i rolnictwa w Polsce, Studia Obszarów Wiejskich, 2, s. 9-17.

Labour Markets and Employability: Trends and Challenges in Armenia, Azerbaijan, Belarus, Georgia, Moldova and Ukraine, 2011, European Training Foundation, Turin.

Lucas R., 1988, On the Mechanics of Economics Development, Journal of Monetary Economics, 22, s. 3-42.

McMahon W.W., 2001, The Impact of Human Capital on Non-Market Outcomes and Feedbacks on Economic Development, [w:]: J. F. Helliwell (red.), The Contribution a Human and Social Capital to Sustained Economic Growth and Well Being, Hull Quebec, Government of Canada.

Miller H.P., 1960, Annual and Lifetime Income in Relation to Education, American Economic Review, 50, s. 962-986.

Nelson R., Phelps E., 1966, Investment in Humans, Technological Diffusion, and Economic Growth, American Economic Review, 56, s. 69-75.

Neycheva M., 2013, Does Higher Level of Education of Labor Force Cause Growth. Evidence from Bulgaria, Eco Change Restruct, 46, s. 321-339.

Parsons D., 1980, Rural Gentrification: the Influence of Rural Settlement Planning Policies, Departamnet of Geography, University of Sussex, Brigton.

Petrolongo B., Pissarides C., 2001, Looking into the Black Box: A Survey of the Matching Function, Journal of Economic Literature, 39, s. 390-431.

Philips M., 1993, Rural Gentrification and the Process of Class Colonization, Journal of Rural Studies, 9, s. 123-140.

\section{Summary}

The aim of this paper is to determine diversification of rural workforce education level in Poland. The research includes comparison regarding education level of these resources in rural-urban system allowing to identify regularity in location of rural workforce characterized by a particular education level. It was assumed in that workforce resources comprise of people at working age. Basing on research findings it may be stated that education level of rural workforce was lower than that in cities and Poland in general, yet compared to 2002 it has improved significantly. Formal qualifications of rural inhabitants at mobile age were higher than of those at immobile age. Distribution of rural labor force with higher and secondary education referred to the location of agglomeration. The proximity of urban and non-agricultural functions were factors contributing to the accumulation of well-educated personnel, as well as remote areas of routes and diverse urban labor markets included areas of high quality human capital outflow. The study also confirmed that agriculture, particularly in areas with predominance (in the past) of state farms unfavorable education structure of labor force has been perpetuated. 